\title{
PENGARUH STATUS GIZI AWAL DAN KONSUMSI CHLORELLA GROWTH FACTOR TERHADAP KELUHAN KLINIS PENDERITA DEMAM BERDARAH DENGUE
}

\author{
(Effect of Pre-Nutritional Status and Consumption of Chlorella Growth Factor (CGF) on Symptom \\ of Dengue Hemorrhagic Fever)
}

Gina Apriani ${ }^{1 *}$, Hardinsyah ${ }^{1}$, dan Yekti Hartati Effendi ${ }^{1}$

1 Departemen Gizi Masyarakat, Fakultas Ekologi Manusia, Institut Pertanian Bogor, Bogor 16680.

* Alamat korespondensi : Departemen Gizi Masyarakat, Fakultas Ekologi Manusia, Institut Pertanian Bogor, Bogor 16680. Email: ginapriani07@yahoo.co.id

\begin{abstract}
The objective of this study was to analyze the effect of pre-nutritional status and consumption of Chlorella Growth Factor (CGF) on symptom of Dengue Hemorrhagic Fever (DHF). Design of this study was a randomized clinical trial with 37 subjects of intervention group and 37 subjects of control group. The subjects were DHF in-patient of economic class of Karya Bhakti Hospital. The criteria for subjects were DHF in-patients (grade II and III), age $\geq 17$ years, fever up to 7 days, serology Dengue Ig $M(+)$, platelet $<100.000 / \mathrm{mm} 3$, not pregnant and not suffering from immune impaired diseases. The result show that effect of pre-nutritional status ( $p>0.01)$ was not significant, but the effect CGF consumption was significant $(p<0.01)$ on clinical symptom of DHF. This implies that CGF reduced the symptom severity of DHF. Further studies required for identify the actual bioactive components of CGF effects on DHF; and effect of selected nutritional biomarkers on DHF.
\end{abstract}

Key words: Dengue Hemorrhagic Fever, pre-nutritional status, chlorella growth factor.

\section{PENDAHULUAN}

Urbanisasi, perubahan iklim dan kemiskinan mempengaruhi rendahnya kepedulian untuk mendukung layanan (promosi) kesehatan. Rendahnya status gizi dan rendahnya daya tahan tubuh mengakibatkan kerentanan individu terserang penyakit infeksi. Status gizi dipengaruhi oleh kualitas dan kuantitas konsumsi pangan, dan status gizi mempengaruhi ketahanan (kesehatan) fisik.

Demam Berdarah Dengue (DBD) telah dikenal di Indonesia sebagai penyakit yang endemis. Jenis yang ditemukan di Indonesia yaitu VDEN-1, VDEN-2, VDEN-3. Kasus yang dilaporkan selama tahun 2009 , tercatat 10 provinsi yang menunjukkan kasus terbanyak, dan Jawa Barat adalah provinsi urutan pertama terbanyak dengan 29.334 kasus 244 meninggal, diantara DKI Jakarta, Jawa Timur, Jawa Tengah, Kalimantan Barat, Bali, Banten, Kalimantan, Sumatera Utara, dan Sulawesi Selatan (Aditama, 2009). Bogor terletak di Provinsi Jawa Barat, dikenal dengan kota hujan karena memiliki curah hujan yang tinggi setiap bulannya. Korban akibat DBD bertambah pada waktu curah hujan meningkat (Supartha, 2008) sehingga kasus DBD di Bogor mudah ditemui di sepanjang tahunnya. Hal ini diperparah dengan status gizi dan kualitas serta kuantitas pangan yang dikonsumsi individu yang rendah, kedua hal tersebut mempengaruhi daya tahan tubuh dalam melawan penyakit. Menurut Khomsan (2008) akibat rendahnya status gizi maka akan terjadi peningkatan kerentanan terhadap infeksi karena daya tahan yang rendah. Rendahnya tingkat kepedulian individu terhadap kebersihan lingkungan menyebabkan tumpukan-tumpukan barang-barang menjadi sarang perlindungan nyamuk termasuk Aedes Aegypti dan Aedes albopictus. Kedua jenis nyamuk tersebut merupakan vektor DBD menyebabkan meningkatnya angka kejadian DBD di Kota Bogor.

Pemulihan penyakit DBD bersifat selflimiting disease yang dapat diartikan dapat sembuh dengan sendirinya. Namun Infeksi Virus Dengue sebenarnya memberikan gejala klinis dengan spektrum luas mulai dari tanpa gejala klinis, demam ringan tidak spesifik Demam Dengue (DD) dan DBD dengan kebocoran plasma yang menimbulkan renjatan (syok) hipovolemik sampai terjadinya perdarahan yang fatal (Dengue Shock Syndrome/ DSS), dengan kesakitan dan kematian yang tinggi (Depkes 2009). Penanganan DBD dilakukan untuk memperhatikan intake cairan selain itu mencegah infeksi sekunder akibat bakteri. Mencegah peningkatan derajat keparahan DD (derajat I) ke dalam DBD (derajat II dan III) 
hingga menjadi tingkat paling parah DSS (derajat IV). Infeksi DD sering dianggap sepele sehingga derajat keparahan infeksi VDEN meningkat menjadi DBD dan DSS. Ciri-ciri DBD dengan tingkat keparahan berat adalah demam tinggi mendadak dengan manifestasi perdarahan dan menimbulkan syok serta kematian.

Program-program dinas kesehatan dan lintas sektor terkait yang dilakukan untuk menangani penanggulangan DBD setiap tahunnya sudah banyak dilakukan namun masih belum cukup, karena masih ditemukan kasus DBD setiap bulannya. Keberhasilan pembangunan kesehatan harus ditunjang dengan partisipasi masyarakat. Beberapa upaya yang dapat dilakukan antara lain menjaga kebersihan lingkungan, serta menjaga kesehatan agar ketahanan tubuh lebih baik.

Chlorella ialah ganggang hijau yang tumbuh di air tawar. Chlorella mengandung air, protein, lemak, karbohidrat, energi, vitamin, mineral, serat, dan klorofil serta Chlorella Growth Factor (CGF). CGF adalah nukleotida-peptida kompleks yang ditemukan dalam inti sel chlorella yang tersusun atas asam nukleat (DNA/RNA), asam amino, vitamin, mineral, protein dan karbohidrat. CGF berperan dalam pertumbuhan, peremajaan dan perbaikan sel dan hanya terkandung dalam chlorella. Penelitian uji klinis ini merupakan kerjasama antara RS Karya Bhakti Bogor, Persatuan Dokter Ahli Penyakit Dalam Cab. Bogor, IPB, dan PT. CNI Jakarta. Penelitian tersebut untuk melihat pengaruh CGF40\% pada pasien DBD. Hasil penelitian tersebut menunjukkan bahwa CGF $40 \%$ terbukti dapat mempercepat kenaikan kadar trombosit serta memperpendek masa perawatan (Effendi et al. 2010). Terkait dengan penelitian tersebut, penulis tertarik untuk mengkaji lebih lanjut mengenai pengaruh status gizi awal dan konsumsi CGF penderita DBD terhadap keluhan klinis baik sebelum maupun saat perawatan di rumah sakit.

\section{METODE PENELITIAN}

\section{Desain, Tempat dan Waktu}

Desain penelitian ini menggunakan data penelitian uji klinis acak terkontrol (randomized controled trial) paralel yaitu suatu studi eksperimental terencana yang dilakukan pada manusia. Pada desain ini subjek yang memenuhi kriteria pemilihan dilakukan randomisasi sehingga terbentuk kelompok kontrol dan intervensi (eksperimen) (Sastroasmoro \& Ismael, 2006). Tempat penelitian di Rumah Sakit Karya
Bhakti (RSKB) Kota Bogor. Waktu pengambilan data sekunder Mei - Oktober 2009. Penelitian ini adalah bagian dari penelitian Efektivitas Pemberian CGF 40\% dalam Mempercepat Peningkatan Trombosit pada Penderita Demam Berdarah Dengue dengan ketua tim peneliti dr. Adi Teruna Effendi, SpPD. PhD.

\section{Jumlah dan Cara Pemilihan Subjek}

Subjek dalam penelitian ini adalah pasien rawat inap Demam Berdarah Dengue (DBD) dewasa ( $\geq 17$ tahun) di paviliun flamboyan kelas III RSKB bulan Mei-Oktober 2009. Populasi dalam penelitian ini adalah pasien rawat inap DBD dewasa ( $\geq 17$ tahun) di RSKB bulan MeiOktober 2009. Cara pemilihan subjek dengan kriteria inklusi (yang diterima) dan ekslusi (yang ditolak). Kriteria inklusi meliputi: 1) pasien rawat inap saat masuk RS, DBD (derajat II dan III); 2) umur 17-60 tahun; 3) demam hingga 7 hari; 4) serologi Dengue Ig $M(+)$; 5) trombosit < 100.000/mm3. Kriteria ekslusi yaitu 1) saat pasien masuk RS. infeksi dengue derajat IV (Dengue Shock Syndrome/DSS); 2) pasien hamil DBD; 3) menderita penyakit dengan gangguan fungsi imun (tuberkulosis, diabetes melitus tipe 2, sirosis, hepatitis atau gagal ginjal kronik). Jumlah subjek minimal pada masing-masing kelompok diperoleh dengan melalui perhitungan statistik sampling yang digunakan oleh dr. Adi Teruna Effendi, SpPD, PhD pada penelitian sebelumnya. Cara penarikan calon subjek ditentukan dengan dengan kriteria inklusi dan ekslusi, dikumpulkan selama penelitian berlangsung (6 bulan) hingga mendapatkan sejumlah 94 pasien. Kriteria selanjutnya yaitu subjek bersedia ikut penelitian dan mau menandatangani informed consent, maka diperoleh sebanyak 74 terdiri atas 37 subjek kelompok kontrol dan 37 subjek intervensi.

Saat masuk pasien diperiksa oleh dokter poliklinik, dokter jaga atau dokter spesialis penyakit dalam, meliputi pemeriksaan fisik dan laboratorium. Selanjutnya pasien rawat inap yang memenuhi kriteria seperti di atas ditawari untuk ikut dalam penelitian. Hanya subjek yang telah menandatangani informed consent yang diikutsertakan sebagai subjek penelitian. Selanjutnya 74 pasien subjek dibagi ke dalam dua kelompok, yaitu kelompok intervensi dan kelompok kontrol. Selama penelitian subjek kelompok intervensi mendapat bahan intervensi CGF dengan kadar $40 \%$ dengan dosis $1 \times 30 \mathrm{ml}$ per hari, serta terapi standar yang dianjurkan WHO 1997. Sedangkan subjek kelompok kontrol hanya mendapat terapi standar WHO saja (Effendi et al., 2010). 


\section{Jenis dan Cara Pengumpulan Data}

Jenis data yang dikumpulkan terdiri atas karakteristik subjek, berat badan dan tinggi badan, keluhan klinis demam awal dan keluhan klinis selama perawatan, jumlah pemberian CGF40\% pada subjek kelompok kontrol serta lama rawat. Prosedur pengumpulan subjek dimulai dengan pengajuan surat persetujuan kaji klinis (ethical clearance) dari komisi etik penelitian klinis Fakultas Kedokteran Universitas Indonesia (FKUI) serta formulir informed consent.

Cara pengumpulan data dengan menyampaikan permohonan izin tim peneliti dr. Adi Teruna Effendi, SpPD., PhD. dan Direktur RSKB untuk menelusuri data di RS Karya Bhakti; penelusuran meliputi rekam medik (sewaktu pasien akan/selama masa rawat inap), hasil pemeriksaan medik oleh tim peneliti dokter spesialis dan dokter ruangan rawat inap Paviliun Flamboyan kelas III, jenis data yang dikumpulkan adalah data sekunder.

\section{Pengolahan dan Analisis Data}

Proses pengolahan data diawali proses entry, editing, cleaning dan coding. Data diolah dengan tabulasi frekuensi dan tabulasi silang. Program komputer yang digunakan untuk database dan penyimpanan adalah Ms. Excell 2007. Analisis data menggunakan program Statistical Program for Social Science (SPSS) 16.0 for windows.

Analisis deskriptif digunakan untuk mendeskripsikan setiap variabel yang diukur dalam penelitian ini, yaitu variabel karakteristik subjek, status gizi awal menurut IMT, keluhan klinis awal yaitu demam sebelum masuk rumah sakit dan keluhan klinis saat perawatan.

Penilaian keluhan klinis DBD saat perawatan diukur dengan menilai 11 jenis keluhan yang dikelompokkan empat (4) yaitu :

- Skor 1 untuk keluhan klinis diare, batuk, pilek dan lainnya

- Skor 2 untuk keluhan klinis nyeri epigastrik, sakit kepala, nyeri otot, nyeri sendi

- Skor 3 untuk keluhan klinis mual/muntah

- Skor 4 untuk keluhan klinis demam dan bintik-bintik merah

Kriteria penentuan kategori keluhan saat perawatan rendah dan sedang berdasarkan median keluhan klinis subjek saat perawatan (7). Kategori keluhan rendah ketika skor keluhan $\leq 7$ dan kategori keluhan sedang ketika skor keluhan $>7$.
Analisis skoring digunakan untuk menilai data dasar (baseline data) yang digunakan untuk analisis lanjutan yang menggunakan program SPSS 16.0 .

Analisis ini digunakan untuk mengetahui homogenitas dua prosedur yang meliputi perbandingan frekuensi yang teramati dan frekuensi yang diharapkan. Analisis kecocokan dengan membandingkan frekuensi yang diteliti (observasi) dan frekuensi harapan, apabila $p$ value < alpha $(\alpha)$ maka dapat diartikan bahwa variabel yang diteliti memiliki frekuensi yang berbeda.

Independent-sample t (uji t) digunakan untuk menguji signifikansi beda rata-rata dua kelompok. Jika Sig (2-tailed) hitung $<\alpha$ maka artinya kedua kelompok tidak memiliki ratarata yang sama.

Wilcoxon sign rank test adalah analisis non-parametrik yang memperhatikan tanda perbedaan (positif atau negatif) juga memperhatikan besarnya beda dalam menentukan ada atau tidaknya perbedaan nyata antara data subjek yang dianalisis dari subjek yang berhubungan (delta keluhan klinis dengan konsumsi CGF pada subjek) (Hasan, 2001). Delta keluhan klinis adalah selisih total keluhan hari ke lima (5) dengan total keluhan hari pertama (1). Delta keluhan klinis mendeskripsikan penurunan keluhan klinis saat perawatan, semakin rendah delta maka dapat diartikan semakin cepat keluhan klinis berkurang, semakin rendah delta maka semakin lambat keluhan klinis berkurang. Jika Asymp. Sig (2-tailed), yang didapat $<1 / 2 \alpha$ maka artinya terdapat perbedaan yang signifikan antara delta keluhan klinis pada subjek yang tidak mengonsumsi dan yang mengonsumsi CGF saat perawatan.

Analisis regresi linear merupakan suatu alat ukur yang juga digunakan untuk mengukur ada atau tidaknya pengaruh antar variabel. Variabel yang akan dianalisis dituliskan pada ruas kiri persamaan dan disebut variabel tidak bebas (dependent) yaitu delta keluhan klinis dan variabel bebas (independent) yaitu pemberian CGF dan status gizi menurut IMT.

Rumus regresi linear adalah sebagai berikut :

$$
Y=a+b_{1} X_{1}+b_{2} X_{2}
$$

Keterangan :

$$
\begin{array}{ll}
\mathrm{Y}=\text { Total keluhan klinis } & \mathrm{X}_{1}=\text { koefisien status gizi } \\
\mathrm{a}=\text { konstanta } & \mathrm{b}_{2}=\text { konsumsi CGF } \\
\mathrm{b}_{1}=\text { status gizi } & \mathrm{X}_{2}=\text { koefesien konsumsi CGF }
\end{array}
$$


Jika Sig. hitung $<\alpha(0.05)$ maka artinya terdapat pengaruh yang signifikan antara delta konsumsi CGF saat perawatan dan status gizi menurut IMT terhadap delta keluhan klinis.

Analisis regresi logistik digunakan untuk melihat pengaruh sejumlah variabel independent (status gizi awal dan konsumsi CGF) terhadap variabel dependen (total keluhan klinis DBD). Nilai eksponensial dari setiap koefisien variabel bebas (exp (B)) merupakan nilai Odds Ratio yang menunjukkan besar dari setiap faktor untuk mengestimasi kemungkinan pengaruh paling besar di antara seluruh variabel dependent.

Rumus regresi logistik adalah sebagai berikut :

$$
Z=\alpha+\beta_{1} X_{1}+\beta_{2} X_{2}
$$

Keterangan :

$\mathrm{Z}=$ Total keluhan klinis $\mathrm{X}_{1}=$ koefisien status gizi

$\alpha=$ konstanta $\quad \beta_{2}=$ konsumsi CGF

$\beta_{1}=$ status gizi $\quad X_{2}=$ koefesien konsumsi CGF

Jika OR = 1 : Tidak ada pengaruh antara konsumsi CGF dengan delta keluhan klinis demam berdarah dengue.

Jika OR $<1$ : Adanya pengaruh konsumsi CGF dengan penurunan delta keluhan klinis demam berdarah dengue.

Jika OR > 1 : Adanya pengaruh konsumsi CGF dengan peningkatan delta keluhan klinis demam berdarah dengue.

Variabel independent yaitu : variabel status gizi subjek dinilai 0 jika normal; 1 jika kurus/gemuk; variabel pemberian CGF subjek dinilai 0 jika tidak diberikan (kontrol), 1 jika diberikan (intervensi). Variabel dependent yaitu delta keluhan klinis saat perawatan dinilai dengan median (nilai tengah) delta keluhan klinis saat perawatan data subjek, yang jatuh pada nilai -7 sehingga variabel ini dinilai 0 jika $\leq-7$ dan nilai 1 jika > -7. Penghitungan Odds ratio adalah sebagai berikut :

Tabel 1. Contoh perhitungan Odds Ratio pengaruh konsumsi CGF terhadap keluhan klinis demam berdarah dengue

\begin{tabular}{lccc}
\hline \multicolumn{1}{c}{ CGF } & $\begin{array}{c}\text { median delta } \\
\text { keluhan klinis } \\
0=\leq-7\end{array}$ & $\begin{array}{c}\text { median delta } \\
\text { keluhan klinis } \\
1=>-7\end{array}$ & Jumlah \\
\hline Ya & $\mathrm{a}$ & $\mathrm{b}$ & $\mathrm{a}+\mathrm{b}$ \\
Tidak & $\mathrm{c}$ & $\mathrm{D}$ & $\mathrm{c}+\mathrm{d}$ \\
Jumlah & $\mathrm{a}+\mathrm{c}$ & $\mathrm{b}+\mathrm{d}$ & $\mathrm{a}+\mathrm{b}+\mathrm{c}+\mathrm{d}$ \\
Odds & $\mathrm{a} / \mathrm{c}$ & $\mathrm{b} / \mathrm{d}$ & \\
\hline Keterangan : OR $=\frac{\mathrm{a} / \mathrm{c}}{\mathrm{b} / \mathrm{d}}=\mathrm{ad} / \mathrm{bc}$ &
\end{tabular}

\section{HASIL DAN PEMBAHASAN}

\section{Karakteristik Subjek}

Karakteristik subjek pada penelitian ini, diidentifikasi untuk mengetahui sebaran umur, jenis kelamin, tinggi badan dan berat badan untuk mengetahui status gizi dari subjek.

\section{Umur dan jenis kelamin}

Sebaran subjek memiliki kisaran umur 17 - 60 tahun. Persentase umur subjek umur 17 40 tahun $(85.14 \%)$ sedangkan persentase umur 41 - 60 tahun (15.86\%). Nilai analisis chi square $\left(X^{2}\right)$ pada variabel umur yaitu 36.541 dengan $p$ value 0.000 ( $\mathrm{P}$ hitung $<\alpha=0.01$ ) dapat diartikan bahwa frekuensi umur subjek tidak sama. DBD adalah penyakit infeksi virus dengue dengan tingkat keparahan II dan III yang ditularkan oleh nyamuk Aedes aegypti dan Aedes albopictus (Soegijanto, 2006b). Sejak tahun 1996 - 2000 proporsi kasus DBD terbanyak pada kelompok umur 4-5 tahun. Tetapi tahun 1998 dan 2000 proporsi kasus pada kelompok 15-44 tahun meningkat. Keadaan tersebut perlu diwaspadai pada kelompok umur remaja dan dewasa (Soegijanto, Sustini, \& Wirahjanto, 2006a).

Sebaran jenis kelamin subjek, laki-laki (50\%) dan perempuan (50\%). Nilai analisis chi square pada variabel umur yaitu 0.216 dengan $p$ value 0.642 ( $p$ hitung $>\alpha=0.01$ ) dapat diartikan bahwa umur subjek sama. Beberapa negara melaporkan banyak kelompok perempuan dengan Dengue Shock Syndrome (DSS) menunjukkan angka kematian yang tinggi daripada laki-laki (Soegijanto, Sustini, \& Wirahjanto, 2006a).

\section{Status Gizi}

\section{Berat badan dan tinggi badan}

Rata-rata berat badan subjek $53.48 \pm$ 11.02 dengan kisaran berat badan $33-83 \mathrm{~kg}$. Rincian subjek intervensi $51 \pm 8.8 \mathrm{~kg}$ dengan kisaran berat badan $33-70 \mathrm{~kg}$ dan subjek kontrol $55.76 \pm 12.48 \mathrm{~kg}$ dengan kisaran berat badan $35-80 \mathrm{~kg}$. Kisaran berat badan menunjukkan keragaman berat badan subjek, subjek kontrol memiliki keragaman berat badan yang lebih bervariasi daripada kelompok intervensi. Nilai $t$ pada variabel berat badan yaitu -0.575 dengan sig. ( $t$ value) 0.567 ( $\mathrm{p}$ hitung $>\alpha=$ 0.01) dapat diartikan bahwa rata-rata berat badan subjek tidak berbeda nyata dengan tingkat kepercayaan 99\%.

Rata-rata tinggi badan subjek $161.14 \pm$ 9.16 dengan kisaran 135 - $182 \mathrm{~cm}$. Rincian sub- 
jek intervensi $161 \pm 10 \mathrm{~cm}$ dengan kisaran 139 $182 \mathrm{~cm}$, dan subjek kontrol $162 \pm 8.1 \mathrm{~cm}$ dengan kisaran 138-175 cm. Kisaran tinggi menunjukkan keragaman tinggi badan subjek, kelompok intervensi memiliki keragaman tinggi badan yang lebih bervariasi daripada subjek kontrol. Kisaran berat badan menunjukkan keragaman berat badan subjek, subjek kontrol memiliki keragaman tinggi badan yang lebih bervariasi daripada kelompok intervensi. Nilai $t$ pada variabel tinggi badan yaitu 0.156 dengan sig. ( $t$ value) 0.876 ( $\mathrm{p}$ hitung $>\alpha=0.01$ ) dapat diartikan bahwa rata-rata tinggi badan subjek tidak berbeda nyata.

\section{Status gizi awal}

Status gizi ialah keadaan yang diakibatkan oleh status keseimbangan antara jumlah asupan (intake) zat gizi dan jumlah yang dibutuhkan (requirement) oleh tubuh untuk berbagai fungsi biologis (pertumbuhan fisik, perkembangan, aktivitas, pemeliharaan kesehatan, dan lain sebagainya). Jika terdapat ketidakseimbangan antara jumlah asupan dan dibutuhkan yang dibutuhkan untuk fungsi biologis maka akan terjadi penurunan/peningkatan status gizi. Salah satu pengukuran yang dapat digunakan adalah dengan menggunakan antropometri, rasio berat badan terhadap tinggi badan atau dikenal dengan Indeks Massa Tubuh (IMT) (Arisman, 2002). IMT dapat diketahui dengan membagi berat badan dalam satuan kilogram $(\mathrm{kg})$ dengan tinggi badan kuadrat dengan satuan meter $(\mathrm{m})$.

Status gizi awal subjek yang disajikan merupakan status gizi berdasarkan IMT saat masuk rumah sakit. IMT subjek $20.59 \pm 4.02$ dengan kisaran IMT 13.01 - 35.56. Rincian IMT subjek intervensi $21.6 \pm 4.84$ dengan kisaran IMT 13 - 35.6 dan subjek kontrol $19.58 \pm 2.80$ dengan kisaran IMT 14.67 - 72. Nilai $t$ pada variabel berat badan yaitu 0.341 dengan sig. ( $T$-value) 0.734 ( $\mathrm{p}$ hitung $>\alpha=0.01$ ) dapat diartikan bahwa rata-rata IMT subjek tidak berbeda nyata dengan tingkat kepercayaan $99 \%$.

Lebih dari separuh subjek berstatus gizi normal (55.41\%) kurus (33.78\%) dan gemuk (10.81\%). Rincian subjek intervensi kurus sebanyak $18.91 \%$ dan normal sebanyak $28.38 \%$. Pada subjek kontrol kurus (14.86\%) dan normal (27.03\%). Nilai analisis chi-square $\left(\mathrm{X}^{2}\right)$ pada variabel kategori IMT yaitu 30.838 dengan $p$ value 0.000 ( $\mathrm{p}$ hitung $>\alpha=0.01$ ) dapat diartikan bahwa rata-rata kategori IMT subjek dapat diartikan bahwa frekuensi umur subjek tidak sama dengan tingkat kepercayaan $99 \%$.

\section{Keluhan Klinis Demam Berdarah Dengue}

\section{Keluhan Klinis Awal (Demam Sebelum Masuk $R S)$}

Demam awal subjek berkisar antara 2 hingga 7 hari sebelum masa perawatan rumah sakit. Rata-rata keseluruhan subjek mengalami demam awal selama $4.27 \pm 1.15$ hari.

Persentase terbesar lama demam pada keseluruhan subjek 5 hari sebelum masuk RS sebanyak $32.43 \%$ dan terkecil 7 hari sebelum masuk RS sebanyak 4.05. Persentase keseluruhan subjek demam 2-3 hari sebelum masuk RS (fase akut) sebanyak 25\%; demam 4-5 hari (fase kritis) 64\% dan demam 6-7 hari (fase kritis) $11 \%$. Jika diamati pada perjalanan alamiah penyakit DBD maka kisaran subjek terbesar berada di fase akut menuju fase kritis yang ditunjukkan pada warna merah muda dan kisaran subjek pada warna kuning (disajikan pada Gambar 1).

Sebaran subjek memiliki kisaran lama demam sebelum masuk RS 2-7 hari. Pada subjek intervensi persentase terbanyak pada pasien demam 5 hari sebelum masuk rumah sakit sebanyak $20.27 \%$ dan persentase terkecil demam 7 hari sebelum masuk rumah sakit, sebesar $2.70 \%$. Demam subjek kontrol dengan lama 4 hari sebelum masuk rumah sakit $20.27 \%$ dan persentase terkecil demam 1 dan 7 hari sebelum masuk rumah sakit, masing-masing $1.35 \%$.

Demam sebelum masuk RS adalah gejala subjektif yang timbul akibat masuk dan berkembangnya virus dengue ke dalam tubuh penderita (viremia). Virus timbul pada gejala klinis yang tampak hingga 5-7 hari setelahnya. Timbulnya keluhan demam $\left(>37.2^{\circ} \mathrm{C}\right)$ 2-5 hari (fase akut), 4-5 hari (fase kritis) dan demam 67 hari (fase kritis) pada penyakit DBD (Effendi et al., 2010; Soegijanto, 2009). Keluhan klinis DBD pada subjek kelompok kontrol maupun intervensi berada pada kisaran 2-7 hari sebelum masa perawatan.

\section{Keluhan Klinis Saat Perawatan}

Jenis keluhan klinis saat perawatan yang diamati meliputi demam, bintik-bintik merah, gangguan pencernaan (mual/muntah, diare dan nyeri epigastrik), nyeri/sakit (sakit kepala, nyeri otot dan nyeri sendi), batuk, pilek, serta keluhan lainnya (lemas, gatal, tidak nafsu makan, kembung, sakit tenggorokan, dan tidak bisa tidur). Berikut ini dibahas keluhan klinis saat perawatan berdasarkan ada tidaknya keluhan klinis menurut jenis keluhan. 


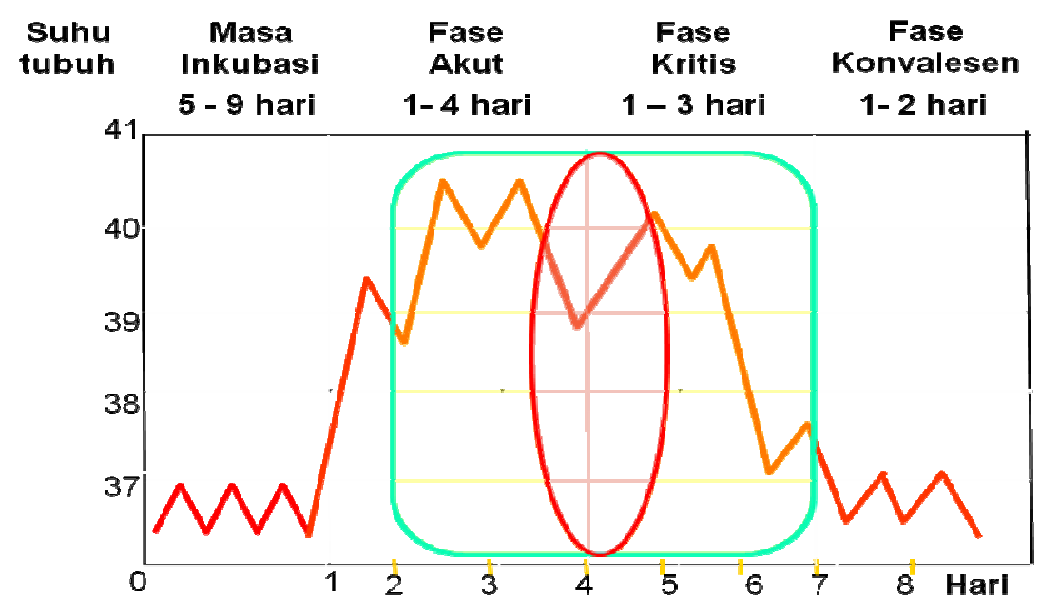

Gambar 1. Perjalanan Alamiah Demam Berdarah Dengue pada Subjek

\section{Keluhan Klinis Demam dan Bintik-bintik Merah}

Subjek mengalami demam (50\%) dan bintik-bintik merah (22.95\%). Rincian subjek intervensi yang mengalami demam (13.51\%) dan bintik-bintik merah (20.27\%); kontrol mengalami demam (36.49\%) dan bintik-bintik merah $(2.70 \%)$.

Suatu tipe demam dan gangguan pencernaan merupakan keluhan yang timbul akibat masuknya organisme asing (agent/virus) ke dalam tubuh penderita (host). Sebesar $90 \%$ pasien dengan demam pada dasarnya merupakan suatu penyakit yang bersifat self-limiting (Nelwan, 2006b) seperti penyakit infeksi misalnya DBD yang disebabkan virus dengue. Bintikbintik merah adalah tanda khas yang ditemukan pada penderita DBD. Bintik-bintik merah disebabkan oleh perdarahan yang tampak pada permukaan kulit.

\section{Keluhan Klinis Gangguan Pencernaan}

Jenis keluhan klinis demam dan gangguan pencernaan yang dialami subjek yaitu nyeri epigastrik (55.41\%), mual/muntah (54.06\%) dan diare (13.52\%). Pada subjek intervensi persentase terbesar keluhan klinis yang dialami ialah mual/muntah (56.76\%) serta nyeri epigastrik (56.76\%) dan persentase terkecil diare $(16.22 \%)$. Pada subjek kontrol persentase terbesar keluhan klinis yang dialami ialah nyeri epigastrik (54.05\%) dan persentase terkecil diare $(16.22 \%)$.

Nyeri epigastrik (abdomen) adalah suatu kegawatan abdomen dengan keluhan yang terjadi secara tiba-tiba. Nyeri abdomen dapat berasal dari organ dalam abdomen termasuk peritoneum viseral (nyeri visceral) atau peritoneum parietal dari otot, lapisan dari dinding perut (nyeri somatik). Pada saat nyeri dirasakan pertama kali, nyeri viseral biasanya ditimbulkan terlokalisasi dan berbentuk khas. Nyeri yang berasal dari viseral dan berlangsung akut biasanya menyebabkan tekanan darah dan denyut jantung berubah, pucat dan berkeringat dan disertai dengan fenomena viseral motor seperti muntah dan diare. Biasanya subjek juga merasa cemas nyeri akibat yang ditimbulkan tersebut. Pada akut abdomen selain nyeri abdomen, subjek juga mengeluhkan keluhan lain seperti mual, muntah, anoreksia, kembung. Gangguan pencernaan merupakan hal yang menyebabkan terganggunya konsumsi makanan. Sehingga kebutuhan gizi pasien menjadi tidak tercukupi.

Diare diartikan buang air besar (defekasi dengan tinja berbentuk cair atau setengah cair/setengah padat), dengan kandungan air pada tinja lebih banyak dari biasanya lebih dari $200 \mathrm{~g}$ atau $200 \mathrm{ml} / 24 \mathrm{jam}$ dapat dikatakan pula frekuensi buang air besar encer lebih dari 3 kali per hari. Diare disebabkan oleh banyak penyebab, salah satunya antara lain infeksi oleh virus yang berperan pada terjadinya diare pada infeksi yaitu faktor kausal (agent) dan faktor penjamu (host). Host adalah kemampuan tubuh untuk mempertahankan diri terhadap organisme yang dapat menimbulkan diare, terdiri atas faktor-faktor daya tangkis atau lingkungan internal saluran cerna antara lain keasaman lambung, motilitas usus, imunitas dan juga lingkungan mikroflora usus. Agent yaitu daya penetrasi yang dapat merusak sel mukosa, kemampuan memproduksi toksin yang mempengaruhi sekresi cairan usus halus serta daya lekat virus (Samadibrata, \& Daldiyono, 2006). 


\section{Keluhan Klinis Nyeri}

Jenis keluhan klinis nyeri yang dialami subjek ialah sakit kepala (47.29\%), nyeri otot (27.02\%) dan nyeri sendi (24.32\%). Keluhan nyeri yang dialami subjek intervensi dengan persentase terbesar ialah sakit kepala (24.32\%) dan persentase terkecil pada nyeri otot (18.91\%). Keluhan nyeri yang dialami subjek kontrol dengan persentase terbesar ialah sakit kepala $(22.97 \%)$ dan persentase terkecil pada nyeri sendi $(4.05 \%)$.

Rasa sakit (nyeri) merupakan keluhan yang sering didapatkan dalam klinik, walaupun istilah "sakit" ini nampaknya sulit didefinisikan. Persepsi orang berbeda-beda, karena keluhan ini berasal dari pengalaman orang yang sulit dilakukan pengukurannya. Aristoteles berpendapat bahwa rasa sakit itu merupakan kualitas keadaan jiwa, suatu keadaan perasaan yang merupakan kebalikan dari senang. Istilah (cephalgia, headache) adalah rasa sakit atau nyeri yang terlokalisasi di kepala dan muka. Sakit kepala disebabkan oleh kelainan vaskular, jaringan saraf, gigi geligi, orbita, hidung serta sinus paranasal serta jaringan lunak di kepala, kulit, jaringan, subkutan, otot, peritoneum di kepala (Dahlan \& Asdie, 2006).

Pada proses inflamasi, proses nyeri stimulus nosiseptor akibat pembebasan berbagai medial, selama proses inflamasi terjadi. Inflamasi terjadi akibat reaksi imunologik yang dimulai oleh adanya antigen.

\section{Keluhan Klinis Batuk, Pilek, dan Lainnya}

Jenis keluhan klinis batuk, pilek dan keluhan lainnya pada subjek dijelaskan sebagai berikut: Subjek mengalami batuk (20.27\%) dan pilek (1.35\%) dan keluhan klinis lain yang terdiri dari lemas, gatal, tidak nafsu makan, kembung, sakit tenggorokan, dan tidak bisa tidur (41.89\%). Keluhan yang dialami subjek intervensi dengan persentase terbesar ialah lainnya (18.91\%) dan persentase terkecil pada pilek (0\%). Keluhan terbesar yang dialami subjek kontrol ialah lainnya (22.97\%) dan persentase terkecil pada pilek (1.35\%). Keluhan klinis batuk dan pilek, serta keluhan lainnya merupakan respon imunitas non spesifik-fisik dalam tubuh ketika masuk virus dengue ke dalam tubuh.

Skoring jenis keluhan klinis pada subjek saat perawatan (5 hari) yang meliputi demam, bintik-bintik merah, nyeri otot pada subjek intervensi dan kontrol berbeda nyata pada uji T karena sig. ( $t$ value) $<\alpha(0.05)$. Sedangkan jenis keluhan mual/muntah, nyeri epigastrik, diare, sakit kepala, batuk, pilek dan lainnya pada subjek intervensi dan kontrol tidak berbeda nyata karena $\mathrm{P}$ hitung $>\alpha(0.05)$ dengan tingkat kepercayaan 95\%.

Perbandingan kategori keluhan klinis pada awal, saat dan akhir perawatan. Kategori keluhan dibagi dua setiap masa perawatan yaitu rendah dan sedang. Pada masa rawat awal dan akhir tidak menunjukkan frekuensi kategori keluhan klinis yang tidak sama pada tingkat kepercayaan 99\%. Namun selama masa rawat menunjukkan $p$ value 0.033 ( $p$ hitung $<\alpha=$ 0.05 ) dapat diartikan bahwa frekuensi kategori keluhan tidak sama selama perawatan dengan tingkat kepercayaan 95\%

\section{Pengaruh Status Gizi Awal dan Konsumsi CGF Terhadap Keluhan Klinis Saat Perawatan}

Analisis Independent-sample t (uji t) menunjukkan bahwa Sig (2-tailed) hitung 0.03 $<\alpha(0.05)$ maka artinya kedua kelompok tidak memiliki rata-rata delta keluhan klinis yang sama.

Analisis Wilcoxon sign rank test menunjukkan bahwa Asymp. Sig (2-tailed) hitung $0.002<1 / 2 \alpha(0.025)$ maka artinya terdapat perbedaan yang signifikan antara delta keluhan klinis pada subjek yang mengonsumsi CGF dan yang tidak mengonsumsi CGF saat perawatan.

Analisis regresi linear dengan persamaan $y=-4.6-0.954$ status gizi awal -0.632 konsumsi CGF. Menunjukkan hasil analisis regresi linear bahwa status gizi awal berdasarkan IMT $(p>0.05)$ artinya tidak mempengaruhi secara nyata terhadap delta keluhan klinis demam berdarah dengue, konsumsi CGF $(p<0.01)$ artinya mempengaruhi secara nyata terhadap delta keluhan klinis demam berdarah dengue.

Terdapat hubungan antara penyakit infeksi dan status gizi kurus. Seseorang yang memiliki status gizi kurus akan mengalami tingkat daya tahan terhadap penyakit menjadi rendah, sehingga mudah terserang penyakit infeksi (Suhardjo, 1989). Salah satu masalah yang juga dihadapi oleh negara berkembang akibat arus globalisasi adalah gizi lebih/gemuk. Masalah gizi lebih dapat menurunkan aktivitas dan efisiensi kerja, terganggunya fungsi organ untuk bekerja dengan normal, karena peningkatan resiko terjadinya penyakit (Mahan, \& Stump, 2005). Hal yang diidentifikasi pada penelitian tidak sesuai dengan pernyataan karena status gizi yang dikaji hanya berdasarkan IMT dan jumlah subjek yang kecil diperkirakan mempe- 
ngaruhi ketidaksesuaian antara teori tersebut dengan kajian penelitian ini.

Konsumsi CGF dapat meningkatkan delta keluhan klinis $(p<0.01)$. Artinya hal tersebut dapat diartikan jika delta lebih rendah maka penurunan keluhan klinis saat perawatan semakin cepat keluhan klinis berkurang.

Hasil analisis regresi logistik dengan persamaan $Z=2.023-0.7$ status gizi awal -1.690 konsumsi CGF, status gizi awal berdasarkan IMT $(p>0.01)$ artinya tidak mempengaruhi secara nyata terhadap delta keluhan klinis demam berdarah dengue dan konsumsi CGF ( $p<$ 0.01 ) berpengaruh secara nyata terhadap delta keluhan klinis demam berdarah dengue. Konsumsi CGF pada subjek intervensi menurunkan delta keluhan klinis sebesar $81.5 \%$ lebih rendah daripada kontrol.

Selama penelitian subjek kelompok intervensi mendapat bahan intervensi CGF dengan kadar $40 \%$ dengan dosis 1 × $30 \mathrm{ml}$ per hari, serta terapi standar yang dianjurkan WHO 1997. Sedangkan subjek kelompok kontrol hanya mendapat terapi standar WHO saja (Effendi et al., 2010).

Chlorella mengandung vitamin, mineral, serat makanan, asam nukleat, asam amino serta berbagai macam enzim, klorofil dan CGF (Chlorella Growth Factor). Chlorella juga mengandung CGF yang memiliki kandungan spektrum kelengkapan macro-micro nutrients yang lengkap dan mineral. Terdapat pula komponen kompleks nucleotida-peptida dalam sel chlorella. Chlorella yang digunakan berkadar $40 \%$. Kesemuanya dapat diduga kuat mempunyai khasiat sebagai antioksidan, sebagai immunomodulator yang berperan membuat sistem imun lebih aktif dalam menjalankan fungsinya menguatkan sistem imun tubuh (imuno stimulator) atau menekan reaksi sistem imun yang berlebihan (imuno supresan) sehingga kekebalan atau daya tahan tubuh kita selalu optimal menjaga kita tetap sehat ketika diserang oleh virus, bakteri atau mikroba lainnya (anonim 2010) dan sebagai metabolomik. Ketiga fungsi utama mencirikan percepatan reproduksi sel (4 sel setiap 20-24 jam). Di tingkat sel kemampuan genetiknya terjadi reaksi berantai dari DNA sampai RNA mengubah menjadi metabolit (proses dalam darah dan hati) ditingkat seluler sel-sel terbarukan atau sel regeneratif. Setiap chlorella memiliki sifat genetik dan keunggulan luar biasa daya ungkit DNA reproduksi sel baru karena kandungan asam nukleat yang terkandung pada CGF. Bioavaibilitas (kemampuan tubuh untuk menyerap/absorb dan digunakan dalam tubuh/utility) chlorella ialah $80 \%$ (Karyadi, 2010).

Pada penelitian ini menggunakan ekstrak chlorella dengan kadar $40 \%$ yang dikenal dengan CGF40\% diduga kuat dapat mempercepat penyembuhan dengan cara menghambat enzim reverse transcriptase sehingga menekan perbanyakan virus. Selain itu, CGF40\% juga meningkatkan imunitas nonspesifik dan spesifik, merangsang peningkatan fungsi produksi sumsum tulang yang berperan dalam pembentukan trombosit; kandungan asam nukleatnya juga berperan membentuk daya tahan tubuh. Interferon merupakan zat yang disekresi secara alami oleh tubuh dan diperkirakan menjadi stimulator fisiologis makrofag. Konsumsi CGF dapat meningkatkan kadar interferon alfa sehingga sel dapat terlindungi dari infeksi virus dengue (Effendi et al., 2010).

\section{KESIMPULAN}

Rata-rata status gizi awal berdasarkan IMT subjek $20.3 \pm 4.02$ (13.01 - 35.56). Lebih dari separuh subjek termasuk status gizi kategori normal (55.41\%) dan kurus (33.78\%).

Persentase subjek sebagian besar masuk RS dengan demam 4-5 hari (64\%) dalam kondisi fase kritis. Jenis keluhan klinis saat perawatan pada subjek meliputi demam (50\%), bintik-bintik merah $(22.95 \%)$, nyeri epigastrik (55.41\%), mual/muntah (54.16\%), sakit kepala (47.29\%) dan jenis keluhan klinis pada intervensi meliputi demam (13.51\%), bintik-bintik merah (20.27\%), nyeri epigastrik (28.38\%), mual/muntah $(28.38 \%)$, sakit kepala (24.32\%) dan jenis keluhan klinis kontrol yang meliputi demam (36.39\%), bintik-bintik merah $(2.70 \%)$, nyeri epigastrik (27.03\%), mual/muntah (25.68\%), sakit kepala (22.97\%).

Status gizi awal menurut IMT ( $p>0.01)$ tidak berpengaruh terhadap penurunan keluhan klinis subjek dan konsumsi CGF $(p<0.01)$ berpengaruh terhadap penurunan keluhan klinis subjek. Konsumsi CGF pada subjek intervensi menurunkan delta keluhan klinis sebesar 81.5\% lebih rendah daripada kontrol.

Meskipun status gizi awal berdasarkan IMT tidak berpengaruh terhadap penurunan keluhan klinis DBD tetapi pentingnya intake makanan dan cairan (minuman) yang memenuhi gizi seimbang tetap diperlukan penderita DBD. Kelemahan pengukuran status gizi awal berdasarkan Antropometri (IMT) diperkirakan mempengaruhi hasil yang dianalisis sehingga 
diperlukan kajian lanjutan terhadap status gizi selain penilaian dengan IMT. Pengaruh intake makanan dalam upaya mengurangi keluhan klinis DBD dapat dilakukan dengan mengonsumsi CGF sehingga diperlukan kajian lanjutan terhadap komponen bioaktif yang terdapat pada CGF.

\section{DAFTAR PUSTAKA}

Aditama TY. 2009. Waspada Demam Berdarah Dengue.http://m.depkes.go.id/index.ph p?option=news\&task=viewarticle\&sid $=36$ 38 [20 Jan 2010].

Anonim. 2010. Sistem Imun Tubuh dan Manfaat Immunomodulator. http://www.stimuno. com [1 Feb 2010].

Arisman. 2002. Gizi dalam Daur Kehidupan. EGC Penerbit Buku Kedokteran, Jakarta.

Effendi AT et al. 2010. Efectivity Of CGF $40 \%$ In Accelerating Thrombocyte Increase In Dengue Hemorrhagic Fever Patients. Handout Seminar Efektivitas Pemberian CGF 40\% Dalam Mempercepat Peningkatan Trombosit Pada Penderita Demam Berdarah Dengue, Jakarta.

Mahan K \& Stump SE. 2005. Krause's Food, Nutrition and Food Therapy. Elvesier, USA.

Karyadi D. 2010. Keunggulan Peran CGF dalam Proses Penyembuhan Penyakit Akut dan Kronik (Degeneratif). Artikel Pribadi, Bogor

Khomsan A. 2008. Gizi Kurang Turunkan Kualitas SDM. http://cetak.kompas.com/ $\mathrm{read} / \mathrm{xml} / 2008 / 06 / 07 / 02203073 /$ gizi.ku rang.turunkan.kualitas.sdm. [22 Mei 2010]

. 2009. El Nino Ketahanan Pangan dan Gizi. http://cetak.kompas.com/ $\mathrm{read} / \mathrm{xml} / 2009 / 08 / 04 / 03303075 /$ el.nino .ketahanan.pangan.dan.gizi [12 Jan 2010]

Samadibrata M. 2006. Nutrisi Enteral. Di dalam: Sudiyono AW et al. Buku Ajar Ilmu Penyakit Dalam Jilid I Revisi IV. Pusat Penerbitan Ilmu Penyakit Dalam FKUI, Jakarta. hlm 56-59.

Sastroasmoro S \& Ismael S. 2006. Dasar-dasar Metodologi Penelitian Klinis. Ed Ke-2. CV. Sagung Seto, Jakarta.

Suhardjo. 1989. Berbagai Cara Pendidikan Gizi Petunjuk Laboratorium. Pusat Antar Universitas Pangan dan Gizi IPB, Bogor.

Soegijanto S. 2009. Penatalaksanaan Demam Berdarah Dengue Pada Anak. http://itd. unair.ac.id/gdl42/gdl.php?mod=browse\& op = read\&id = itdunair--soegijanto-12 [9 Feb 2010]

Soegijanto S, Sulistini $F$ \& Wirahjanto A. 2006a. Epidemiologi Demam Berdarah Dengue. Di dalam: Soegijanto S. Demam Berdarah Dengue Edisi 2. Airlangga University Press, Surabaya. hlm 1-9.

Soegijanto S. 2006b. Aspek Imunologis Penyakit Demam Berdarah Dengue. Di dalam: Soegijanto S. Demam Berdarah Dengue Edisi 2. Airlangga University Press, Surabaya. hlm. 169-200. 